\title{
Cherokee Language
}

National Cancer Institute

\section{Source}

National Cancer Institute. Cherokee Language. NCI Thesaurus. Code C153883.

An Iroquoian language spoken by the Cherokee people. 